\title{
Heavy Metal Content of Cocoa Plantation Soil in East Kolaka, Indonesia
}

\author{
ZUL ARHAM $^{1 *}$, LA ODE ASMIN ${ }^{1}$, ROSMINI $^{1}$ and MUHAMMAD NURDIN²** \\ ${ }^{1}$ Department of Mathematics and Natural Sciences, Faculty of Tarbiyah, \\ Institute Agama Islam Negeri (IAIN) Kendari 93117 - Souteast Sulawesi, Indonesia. \\ ${ }^{2}$ Department of Chemistry, Faculty of Mathematics and Natural Sciences, Universitas Halu Oleo, \\ Kendari 93232 - Southeast Sulawesi, Indonesia. \\ ${ }^{* *}$ Corresponding author E-mail: arhamzul88@yahoo.com, mnurdin06@yahoo.com
}

http://dx.doi.org/10.13005/ojc/330314

(Received: May 05, 2017; Accepted: May 31, 2017)

\begin{abstract}
Investigations of $\mathrm{pH}$ and heavy metals contents of $\mathrm{Pb}, \mathrm{Cd}, \mathrm{Ni}, \mathrm{Cu}$, and $\mathrm{Zn}$ in cocoa plantations soil of East Kolaka has been conducted by using pH starter Ohaus 3000 and Atomic Absorption Spectroscopy (AAS) Shimadzu AA6300. Based on the investigation, it is known that acidic soil plantation with $\mathrm{pH}$ ranges between 4.45 to 6.26 , and also contains $\mathrm{Pb}, \mathrm{Cd}, \mathrm{Ni}, \mathrm{Cu}$, and $\mathrm{Zn}$ with an average concentration $(\mathrm{mg} / \mathrm{kg})$ are $1.45,0.02,0.85,0.77$, and 1.49 , respectively. The existence of $\mathrm{Pb}$ and $\mathrm{Cd}$ in plantation soil have been exceeded the WHO permissible, whereas $\mathrm{Ni}, \mathrm{Cu}$, and $\mathrm{Zn}$ is still within the permissible limits. Acidic soil plantation will give opportunity metal ions such as $\mathrm{Pb}^{2+}$, $\mathrm{Cd}^{2+}, \mathrm{Ni}^{2+}, \mathrm{Cu}^{2+}, \mathrm{Zn}^{2+}$, and $\mathrm{Al}^{3+}$ absorbed by plants. Thus causing the accumulation in plant tissues and make the cocoa plants stress of heavy metals.
\end{abstract}

Keywords: East Kolaka, cocoa plantation soil, heavy metals, pH, cocoa plant (Theobroma cacao L.)

\section{INTRODUCTION}

The use of phosphate fertilizers and pesticides in an effort to increase crop production has been reported as a concern all over the world, both governments and environmental agencies ${ }^{1,2}$. The use of fertilizer can increase the concentration of heavy metals on the soil of cocoa plantation ${ }^{3}$, while the use of pesticide in only distributed approximately $15 \%$ in the crop and the rest is distributed in the soil, so it could eventually lead to heavy metal pollution in plantation soil4.

Accumulation of heavy metal in plantation soil will have an impact on crops ${ }^{5}$ and humans when the crops are consumed through the food chain ${ }^{2}$. Several studies on the effect of heavy metals in the crop explained that heavy metals will affect growth, metabolism, inhibits the action of enzymes, and damage the structure of crop cells $s^{6,7}$. 
Special to the cocoa crop, Reis etal., reported that $\mathrm{Pb}$ cause structural changes in mesophyll cell, the membrane disorganization thylacoidal, and chloroplast unfavorable developments ${ }^{8}$. In addition, $\mathrm{Pb}$ is also causing changes in the mitochondria, the outbreak of the nuclear membrane in root cells, and based on the analysis of proteomics with using gel electrophoresis two-dimensional and mass spectroscopy, exclusively illustrates that the stress of $\mathrm{Pb}$ causes the activity of proteins germination of cacao crop disrupted. In humans, heavy metals have also been reported as a harmful substance to the body $\mathrm{y}^{9,10}$. $\mathrm{Pb}$ can lead to damage of hematopoietic system, hematic, renal and gastrointestinal. $\mathrm{Cu}$ in the body causing insomnia, osteoporosis, liver disease, cancer, migraine, loss of memory, and gum disease ${ }^{11}$. $\mathrm{Cd}$ causes kidney dysfunction, lung damage, and bone fracture ${ }^{12}$.

In recent years, the heavy metal content in cocoa crop has been studied and reported ${ }^{13-16}$. This study is based on the increasing needs of the community to the cocoa product such as chocolate. Chocolate is reported to have health benefits such as reducing the risk of cardiovascular disease, cancer, diabetes, impotence, and hypertension 17-20. In Switzerland, the chocolate consumption in 2014 was about $9 \mathrm{~kg} /$ person/year ${ }^{21}$.

East Kolaka is one of the regencies located in Southeast Sulawesi and the second largest region in Indonesia with produce 146 tons per year of $\mathrm{cocoa}^{22}$. Increasing activity of anthropogenic such as the use of phosphate fertilizers and pesticides in the cocoa plantation in East Kolaka can lead to accumulation of heavy metal which will eventually contaminate the environment of a plantation. In generally, the soil in Southeast Sulawesi has contained the elements of heavy metals that have been reported by Nurdin et al..23,24. It is can inhibit of cocoa plant growth so still needed the treatment for the management of the cocoa plant. Based on discussions with the owner of the plantation, it is known that the cacao crop age ranges from 10 to 20 years. Fertilizer application is done within 6 months while spraying pesticides on crops routinely every 2 weeks. Based on this problem, this study aims to investigate the content of heavy metals such as $\mathrm{Pb}, \mathrm{Cd}, \mathrm{Ni}, \mathrm{Cd}$, and $\mathrm{Zn}$ in the soil of cocoa plantation of East Kolaka. In addition, the purpose is also to identify of metal pollution potential through determination of $\mathrm{pH}$ value of plantation soil.

\section{EXPERIMENTAL}

\section{Sampling location}

Sample location was conducted in Anggaloosi and Lamoare (Figure 1). The selection of soil sample by the random method with a depth of $\pm 30 \mathrm{~cm}$. Soil samples were stored in polyethylene bags in preparation for the investigation.
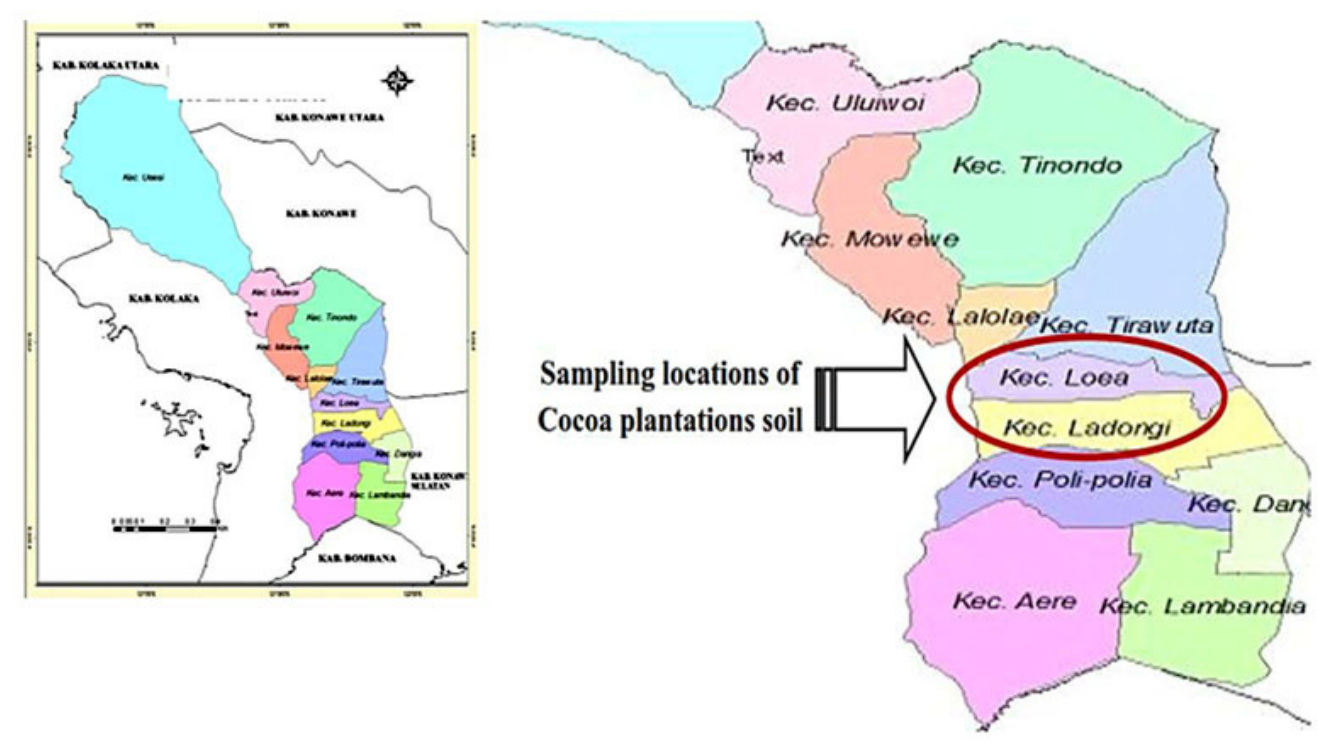

Fig. 1: Sampling location of cocoa plantations soil in East Kolaka 


\section{Sample preparation}

Soil samples were dried at $105^{\circ} \mathrm{C}$ for 6 hours, then refined with a sieve size $<2 \mathrm{~mm}$. Samples of fine soil will be used for all stages of analysis. Sample of soil from Anggalosi labeled I.1I.5 for the location I, II.1-II.5 label for the location II, and label III.1-III.5 for the location III. The soil samples from the Lamoare labeled IV.1-IV.5 and V.1-V.4.

\section{Cocoa Plantation Soil Investigation}

The investigation conducted in this study consisted of the $\mathrm{pH}$ analysis, and the total content of heavy metals $\mathrm{Pb}, \mathrm{Cd}, \mathrm{Ni}, \mathrm{Cu}$, and $\mathrm{Zn}$ in plantation soil. An analysis of $\mathrm{pH}$ carried out by using $\mathrm{pH}$ starter Ohaus 3000. A total of $1 \mathrm{~g}$ of a soil sample mixed with $2 \mathrm{~mL}$ of distilled water. The mixture was then stirred using a magnetic stirrer for 30 minutes and measured value of acidity $(\mathrm{pH})$. Analysis of heavy metals such as $\mathrm{Pb}, \mathrm{Cd}, \mathrm{Ni}, \mathrm{Cu}$, and $\mathrm{Zn}$ in soil samples involves using Atomic Absorption Spectroscopy (AAS) Shimadzu AA6300. A total of $5.00 \mathrm{~g}$ soil samples $<2 \mathrm{~mm}$ is inserted into a plastic bottle and shake then added $20 \mathrm{~mL}$ of extracting diethylene triamine penta acetate (DTPA) pH 7.3. The filtrate obtained was analyzed by different wavelengths of each metal. Measurement of $\mathrm{Pb}, \mathrm{Cd}, \mathrm{Ni}, \mathrm{Cu}$, and $\mathrm{Zn}$ were $217.00 \mathrm{~nm}, 228.80 \mathrm{~nm}, 232.00 \mathrm{~nm}, 324.80 \mathrm{~nm}$, and $636.00 \mathrm{~nm}$, respectively.

\section{RESULTS AND DISCUSSION}

\section{Analysis of heavy metal content}

Based on Figure 2, cocoa plantations soil in East Kolaka for sampling location I, II, III, IV, and $\mathrm{V}$ contains $\mathrm{Pb}$ metals with a concentration were $1.436 \mathrm{mg} / \mathrm{kg}, 1.98 \mathrm{mg} / \mathrm{kg}, 1.004 \mathrm{mg} / \mathrm{kg}, 0.90 \mathrm{mg} / \mathrm{kg}$, and $2.0775 \mathrm{mg} / \mathrm{kg}$, respectively. $\mathrm{Pb}$ concentration
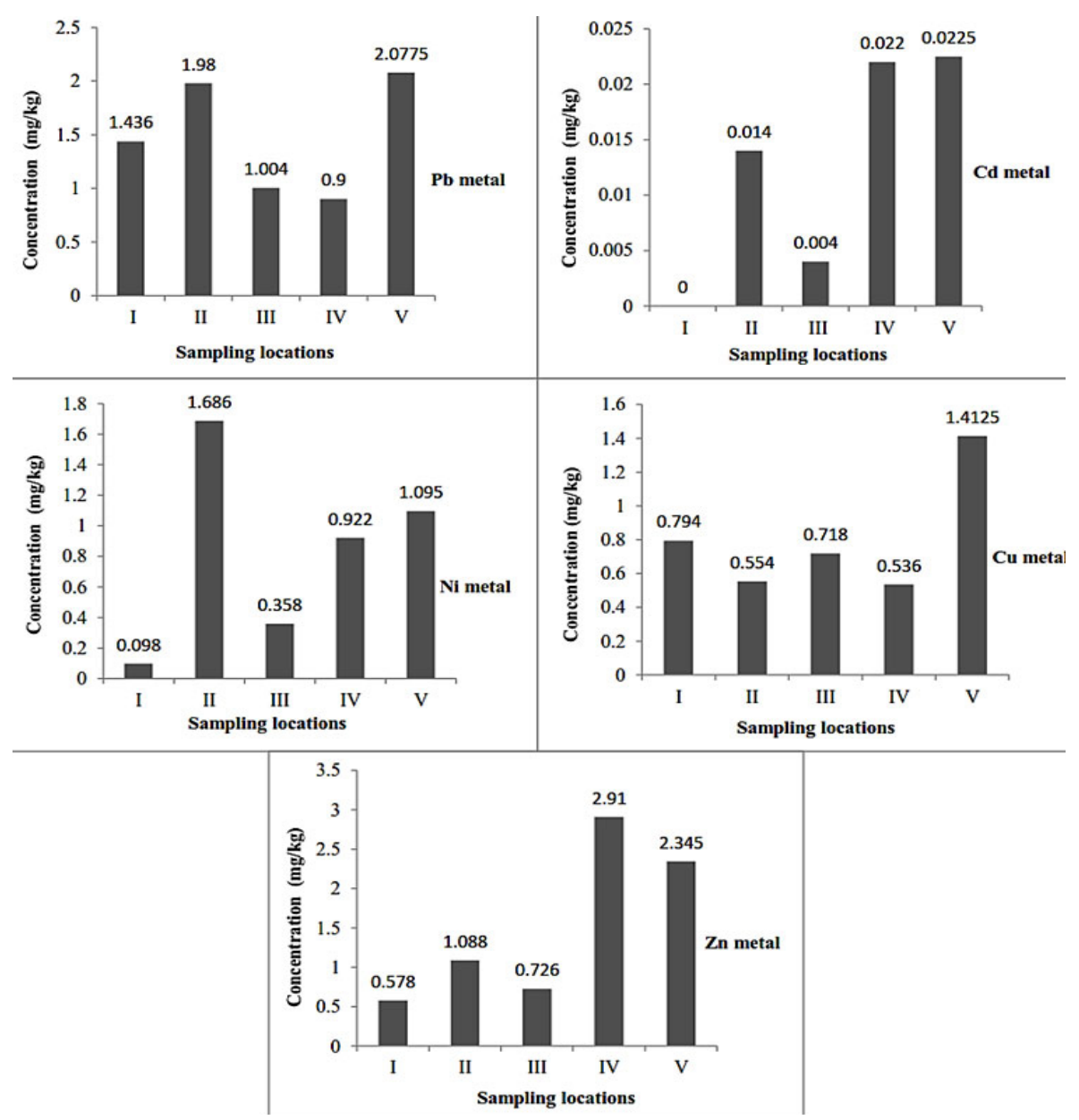

Fig. 2: Graphs of heavy metals content of cocoa plantations soil in East Kolaka 
obtained from the analysis was greater than the results reported by Nazir et al., and Adewole et al., with concentration range were 0.061-0.461 $\mathrm{mg} / \mathrm{kg}$ and $0.01 \mathrm{mg} / \mathrm{kg}$, respectively ${ }^{25,26}$. However resemblance by Ogunlade et al., and Ekpete et al., with a concentration range were $0.50-0.86 \mathrm{mg} / \mathrm{kg}$ and $0.669-2.624 \mathrm{mg} / \mathrm{kg}$, respectively $\mathrm{y}^{2,28}$.

Cd metals content for sampling locations I, II, III, IV, and V were $<0.01 \mathrm{mg} / \mathrm{kg}, 0.014 \mathrm{mg} / \mathrm{kg}, 0.004$ $\mathrm{mg} / \mathrm{kg}, 0.022 \mathrm{mg} / \mathrm{kg}$, and $0.0225 \mathrm{mg} / \mathrm{kg}$, respectively. Cd concentration obtained from the analysis has similarity values reported by Ogunlade et al., Nazir et al., and Adewole et al. with concentration range were $0.02-0.05 \mathrm{mg} / \mathrm{kg}, 0.029-0.328 \mathrm{mg} / \mathrm{kg}$; and $0.01-0.08 \mathrm{mg} / \mathrm{kg}$, respectively ${ }^{2,25,26}$. But smaller than reported by Ghorbani et al., Gitet et al., Ekpete et al., Hugo et al., and Mico et al., with a concentration range were $0.12-0.33 \mathrm{mg} / \mathrm{kg}, 0.83 \mathrm{mg} / \mathrm{kg}, 0.049$ $0.089 \mathrm{mg} / \mathrm{kg}, 0.31-1.52 \mathrm{mg} / \mathrm{kg}$, and $0.15-0.88 \mathrm{mg} /$ $\mathrm{kg}$, respectively $1,27-30$.

Ni metals content for sampling locations I, II, III, IV, and V with a concentration were 0.098 $\mathrm{mg} / \mathrm{kg}, 1.686 \mathrm{mg} / \mathrm{kg}, 0.358 \mathrm{mg} / \mathrm{kg}, 0.922 \mathrm{mg} / \mathrm{kg}$, and $1.095 \mathrm{mg} / \mathrm{kg}$, respectively. This result was much greater than that reported Ogunlade et al., Adewole et al., and Ahaneku et al. with concentration range

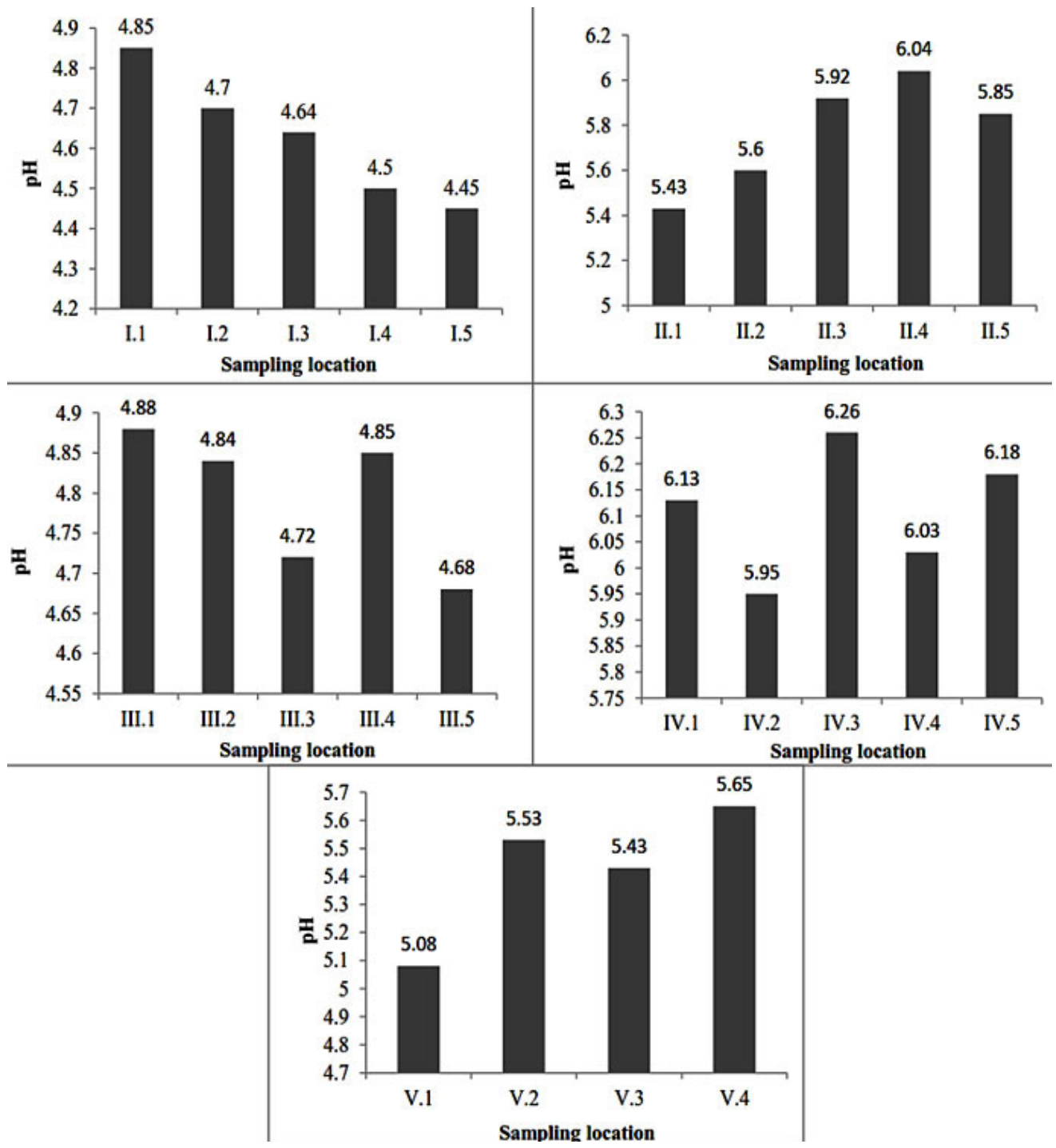

Fig. 3: Graphs of the pH value of cocoa plantations soil in East Kolaka 
were $0.23-0.42 \mathrm{mg} / \mathrm{kg}, 0.02-0.03 \mathrm{mg} / \mathrm{kg}$, and 0.01 $0.91 \mathrm{mg} / \mathrm{kg}$, respectively ${ }^{2,26,31}$. But much smaller than reported by Nartey et al., and has similarities with Nazir et al. with a concentration range from $0.150-1.031 \mathrm{mg} / \mathrm{kg}^{3,25}$.

Cu metal content for sampling location I, II, III, IV, and V with a concentration were $0.794 \mathrm{mg} /$ $\mathrm{kg}, 0.554 \mathrm{mg} / \mathrm{kg}, 0.718 \mathrm{mg} / \mathrm{kg}, 0.536 \mathrm{mg} / \mathrm{kg}$, and $0.8029 \mathrm{mg} / \mathrm{kg}$, respectively. This result was much greater than that reported Nazir et al., and similar by Adewole et al., with concentration range 0.536-1.504 $\mathrm{mg} / \mathrm{kg}$, but much smaller than the concentrations reported by Ekpete et al. with a concentration range 2.670-6.417 mg/kg 25,26,28.

Zn metals content for sampling location I, II, III, IV, and V with a concentration were $0.578 \mathrm{mg} /$ $\mathrm{kg}, 1.088 \mathrm{mg} / \mathrm{kg}, 0.726 \mathrm{mg} / \mathrm{kg}, 2.91 \mathrm{mg} / \mathrm{kg}, 2.345$ $\mathrm{mg} / \mathrm{kg}$, respectively. This result was much greater than that reported Nazir et al., and Adewole et al., with a concentration range was 0.033-0.349 $\mathrm{mg} / \mathrm{kg}$ and $0.41-0.46 \mathrm{mg} / \mathrm{kg}$, respectively ${ }^{25,26}$, but much smaller than reported by Nartey et al., and Ekpete et al. with a concentration was $14.50 \mathrm{mg} / \mathrm{kg}$ and $2.670-6.417 \mathrm{mg} / \mathrm{kg}$, respectively ${ }^{3,28}$.

In general, heavy metals content of $\mathrm{Pd}$ and $\mathrm{Cd}$ in cocoa plantation soil of East Kolaka have been exceeded the WHO permissible, whereas $\mathrm{Ni}, \mathrm{Cu}$, and $\mathrm{Zn}$ are still within the permissible limits. WHO permissible limits for heavy metals $\mathrm{Pb}, \mathrm{Cd}, \mathrm{Ni}, \mathrm{Cu}$, and $\mathrm{Zn}$ in soil was $0.05-0.1 \mathrm{mg} / \mathrm{kg}, 0.005-0.01 \mathrm{mg} /$ $\mathrm{kg}, 0.5-6,5 \mathrm{mg} / \mathrm{kg}, 0.05-1.5 \mathrm{mg} / \mathrm{kg}$, and $5.0-15.0 \mathrm{mg} /$ $\mathrm{kg}$, respectively.

\section{Analysis of pH soil of cocoa plantations}

Figure 3 shows the $\mathrm{pH}$ value of the cocoa plantations soil in East Kolaka. Cocoa plantation soil for the location of the I, II, III, IV and V were in the range 4.45-4.85, 5.43-6.04, 4.68-4.88, 5.95-6.26, and 5.08-5.65, respectively. The location I and III has a more acidic $\mathrm{pH}$ values with an average value of 4.62 and 4.79 compared to location II, IV, and V with the average value were $5.84,6.11$, and 5.42 , respectively. The $\mathrm{pH}$ soil conditions obtained were similar to those reported Ogunlade et al. Ahaneku et al., Yatno et al., and was generally lower than that determined by $\mathrm{WHO}^{2,31,32}$. Acidic soil properties cocoa plantations can be caused by the high content of $\mathrm{Al}^{3+}$ ion and low content of bases that can be exchanged such as $\mathrm{Ca}^{2+}, \mathrm{Mg}^{2+}, \mathrm{K}^{+}$and $\mathrm{Na}^{+}$, and also caused the increasing use of fertilizers ${ }^{32,33}$.

Low soil acidity will cause problems for microbial activity ${ }^{34}$, allows the formation of $\mathrm{Al}^{3+}$ ions to be more soluble in the $\mathrm{pH}$ range of $<5^{35}$, which is reported ions was toxic to plants when in solution land exceeds $60 \%$ cation exchange capacity (CEC) of the soil ${ }^{36,37}$. Stress metals Al reported to inhibit root growth $^{38}$, increasing the thickness of lateral roots and change the color of the roots become brown ${ }^{39}$, interfere with the respiration of roots and enzymatic reactions of glucose phosphorylation ${ }^{40}$, and reducing crop production ${ }^{35}$.

\section{CONCLUSION}

Based on the investigation, the average content of heavy metals $\mathrm{Pb}, \mathrm{Cd}, \mathrm{Ni}, \mathrm{Cu}$, and $\mathrm{Zn}$ were $1.45 \mathrm{mg} / \mathrm{kg}, 0.02 \mathrm{mg} / \mathrm{kg}, 0.85 \mathrm{mg} / \mathrm{kg}, 0.77 \mathrm{mg} /$ $\mathrm{kg}$, and $1.49 \mathrm{mg} / \mathrm{kg}$, respectively. The existence of $\mathrm{Pb}$ and $\mathrm{Cd}$ in cocoa plantations soil of East Kolaka have been exceeded the WHO permissible, whereas $\mathrm{Ni}, \mathrm{Cu}$, and $\mathrm{Zn}$ were still within the permissible limits. Soil conditions cocoa was acidic with the $\mathrm{pH}$ concentration range between 4.45 to 6.26. Conditions such as these will provide opportunities harmful metal ions such as $\mathrm{Pb}^{2+}, \mathrm{Cd}^{2+}, \mathrm{Ni}^{2+}, \mathrm{Cu}^{2+}$, $\mathrm{Zn}^{2+}$, and $\mathrm{Al}^{3+}$ absorbed by the cocoa crop in the excess amount that will accumulate and poison the crops.

\section{ACKNOWLEDGEMENT}

The researcher would like to thank The LPPM - IAIN Kendari for the financial support.

\section{REFERENCES}

1. Ghorbani, H.; Moghadas, N.H.; Kashi, H. J. Agricul. Sci. Technol., 2015, 17, 1025-1040.

2. Ogunlade, M.O.; Agbeniyi, S.O. African J.
Agricul. Res., 2010, 6, 3725-3728.

3. Nartey, V.K.; Haizel, M.; Doamekpor, L.K.; Dankyi, E. J. Natur. Sci. Res., 2012, 2, 2224- 
3186.

4. Leonila, M.V. Ext. Bulletin, National crop protection centre University of Philippines. 2002, 1-7.

5. Chibuike, G.U.; Oblora, S.C. Appl. Environ. Soil Sci. J., 2014, 1-12.

6. Yourtchi, M.S.; Bayat, H.R. Int. J. Agricul. \& Crop Sci., 2013, 6, 1099-1103.

7. Tan, Y.F.; Nicholas, O'T.; Nicolas, L. T.; Harvey, M. Plant Physiology, 2010, 152, 747-761.

8. Reis, G.S.M.; Alex-Alan, F.A.; Nicolle, M.A.; Andressa, V.C.; Pedro, A.O.M.; Carlos, P.P. Plos one. 2015, 1-26.

9. Paul, B.; Nesterenko, P.; Nurdin, M.; Haddad, P.R. Anal. Commun., 1998, 3517-20.

10. Maulidiyah; Halimatussadiyah; Susanti, F.; Nurdin, M.; Ansharullah. J. Agroteknos, 2014, 4, 112-118.

11. Aikpokpodion, P.E.; Atewola-Odule, O.C.; Osobamiro, T.; Oduwole, O.O.; Ademola, S.M. J. Chemical \&Pharmaceu. Res., 2013, 5, 8898.

12. Hii, C.L.; Law C.L.; Suzannah, S.; Misnawi; Cloke, M. Asian J. Food \& Agro-Industry, 2009, 2, 702-722.

13. Bertoidi, D.; Alice, B.; Federica, C.; Augusta, C.; Roberto, L. Food Control., 2016, 65, 4653.

14. Ramtahal, G.; Yen, I.C.; Bekele, I.; Bekele, F.; Wilson, L.; Maharaj, K.; Harrynanan, L. Food \& Nutrition Sci., 2016, 7, 37-43.

15. Amankwaah, D.; Asante, N.W.; Awudza, J.; Afful S. Analysis Food Science \& Technol., 2015, 16, 225-235.

16. Ackah, J.E. Distribution of heavy metals in cocoa farm soils in the Western Region of Ghana. Thesis. Deparment of Chemistry, 2012, University of Ghana.

17. Selmi, C.; Cocchi, C.A.; Lanfredini, M.; Keen, C.L. Mol. Nutr. Food Res., 2008, 52, 13401348.

18. Mhd Jalil, A.M.; Ismail, A. Molecules, 2008, 13, 2190-2219.

19. Dillinger, T.L.; Barriga, P.; Escárcega, S.; Jiminez, M.; Lowe, D.S.; Grivetti, LE. J. Nutrition, 2000, 130, 2057-2072.

20. Taubert, D.; Roesen, R.; Schömig, E. Arch. Intern. Med., 2007, 167, 626-634.

21. Bertoldi, D.; Barbero, A.; Camin, F.; Larcher, R.; Caligiani, A. Food Control., 2016, 65, 46-
53.

22. Central Statistics of Sultra Goverment. Provinsi Sulawesi Tenggara dalam Angka 2016.

23. Nurdin, M.; Maulidiyah; Watoni, A.H.; Abdillah, N.; Wibowo, D. Int. J. ChemTech Res., 2016, 9, 483-491.

24. Nurdin, M.; Zaeni, A.; Maulidiyah; Natsir, M.; Bampe, A.; Wibowo, D. Orient. J. Chemistry, 2016, 32, 2713-2721.

25. Nazir, R.; Muslim, K.; Muhammad, M.; Hameed, U.R.; Naveed, U.R.; Surrya, S.; Nosheen, A.; Muhammad, S.; Mohib, U.; Muhammad, R.; Zeenat, S. J. Pharmaceu. Sci. \& Res., 2015, 7, 89-97.

26. Adewole, E.; Ogunmodede, O.T.; Talabi, J.; Ajayi, O.O.; Oso, O.A.; Lajide, L. J. Chemical \& Pharmaceutical Res., 2011, 3, 544-552.

27. Gitet, H.; Masho, H.; Mehari, M.; Yirgaalem, W.; Dawit, G.; Desta G. Environ Monit Assess, 2016, 188, 500.

28. Ekpete, O.A.; Horsfall, M.J. Res. J. Chem. Sci., 2011, 1, 10-17.

29. Hugo, A.H.Y.; Miguel, A.H.R.; Luis, G.M.M.; Nelino, F.R.; Gilmer, N.T. Acta Agronomica. 2012, 61, 309-314.

30. Mico, C; Peris M; Sanchez, J; Recatala, L. Spanish J. Agricultural Res., 2006, 4, 363372.

31. Ahaneku, I.E.; Bashiru, O.S. Pol. J. Environ. Study, 2014, 23, 1091-1100.

32. Yatno, E.; Sudarsono, B.; Mulyanto; Iskandar. J. Soil \& Climate, 2015, 39, 109-118.

33. Vincent, K.N.; Maxwell, H.; Louis, K.D.; Enoch, D. Studies on the contribution of fertilizers to heavy metals levels in soils and cocoa from some cocoafarms in the Western Region of Ghana. 2012.

34. Solomon, D. Presentation on the relationships existing in minerals soil between $\mathrm{pH}$ one the one hand and the activity of Microorganisms and the availability of plant nutrients oh the other. Bahir Dar University. 2008, Bahir Dar, Ethiopia.

35. Reece, J.B.; Lisa, A.U.; Michael, L.C.; Steven, A.W.; Peter, V.M.; Robert, B.J. Campbell Biology. Ninth Edition. Benjamin Cummings. 2011, San Francisco.

36. Hardjowigeno, S. Soil Classification and pedogenesis. Academy Pressindo. 2003, 
Jakarta.

37. Rachim, D.A. Fundamentals Genesis Land. Department of Soil Science and Land Resources Fakulstas Agriculture, 2007, Bogor.
38. Ma, J.F.; Ryan, P.R.; Delhaize, E. Trends in Plant Sci., 2001, 6, 273-278.

39. Mossor-Pietraszewska. Acta Biochimica Polonica, 2001, 48, 673-686.

40. Rout, G.R.; Samantaray, S.; Das, P. Agronomie, 2001, 21, 3-21. 